\title{
Naphthaleneacetic Acid and Ethephon Are Florigenic in the Biennial Apple Cultivars Golden Delicious and York Imperial
}

\author{
Steven McArtney ${ }^{1,3}$ \\ Department of Horticultural Science, North Carolina State University, \\ Mountain Horticultural Crops Research and Extension Center, 455 Research \\ Drive, Mills River, NC 28759
}

Duane Greene

Stockbridge School of Agriculture, 121 Stockbridge Hall, 80 Campus Center Way, University of Massachusetts, Amherst, MA 01003

Tory Schmidt

Washington Tree Fruit Research Commission, 1719 Springwater Avenue, Wenatchee, WA 98801

\section{Rongcai Yuan ${ }^{2}$}

Alson H. Smith, Jr. Agricultural Research and Extension Center, Virginia Polytechnic Institute and State University, 595 Laurel Grove Road, Winchester, VA 22602

Additional index words. Malus $\times$ domestica Borkh., biennial bearing, floral development

Abstract. 'Golden Delicious' and 'York Imperial' are apple cultivars that are prone to develop a biennial bearing habit. A successful chemical thinning program with carbaryl plus 6-benzyladenine applied at the $10-\mathrm{mm}$ fruit diameter stage reduced cropload and increased return bloom of 'York Imperial', although the improvement in return bloom resulting from chemical thinning was insufficient to ensure a commercial cropload in the year after treatment (fewer than $\mathbf{1 0} \%$ of spurs developing flowers). A chemical thinning program with multiple applications of a naphthaleneacetic acid (NAA) and ethephon mixture during the period from 36 to 73 days after bloom increased return bloom of 'York Imperial' trees to commercially acceptable levels (25\% or greater of spurs flowering). NAA applied during the period from 50 to 100 days after bloom (summer NAA program) or from 110 to 140 days after bloom (preharvest NAA program) increased return bloom of 'Golden Delicious'. When aminoethoxyvinylglycine (AVG) was included with the first NAA spray in a summer program, the efficacy was reduced, indicating that ethylene may be partly involved in the florigenic activity of NAA. Dissection of 'Golden Delicious' buds sampled from three locations (Asheville, NC; Amherst, MA; Wenatchee, WA) at ₹14-day intervals beginning 50 days after bloom indicated that the time of floral transition (doming of the meristem apex) occurred during the period from 65 to 105 days after bloom at each location. Thus, NAA applications in a summer program for return bloom coincided with the period when floral determination normally occurred. Preharvest NAA programs effectively promoted return bloom in the experiments where a summer NAA program was also effective. These responses indicate that NAA can trigger floral development within vegetative buds relatively late in the summer and outside of the time period when it is generally believed possible to influence flower bud formation.

Many important apple (Malus $\times$ domestica Borkh.) varieties develop a biennial bearing habit, in which there is a repeating cycle of

\footnotetext{
Received for publication 15 Mar. 2013. Accepted for publication 16 Apr. 2013.

We thank J.D. Obermiller for contributions to this project.

${ }^{1}$ Southeast Apple Specialist (North Carolina, South Carolina, Georgia, Tennessee).

${ }^{2}$ Deceased.

${ }^{3}$ To whom reprint requests should be addressed; e-mail steve_mcartney@ncsu.edu.
}

a heavy crop 1 year followed by a light crop or no crop in the next year. Regulating the flower bud formation process to restore a more equal balance between vegetative and reproductive spurs is one strategy for restoring trees from a biennial bearing habit to consistent cropping. Early removal of fruit from apple spurs can promote return bloom (Aldrich, 1932; Aldrich and Fletcher, 1932; Harley and Masure, 1937; Harley et al., 1934). An effective chemical fruit thinning program reduces the number of fruit per tree or per spur, thereby increasing the probability that the terminal axillary meristem on a flowering or fruiting spur will develop reproductive structures. However, cultivars with a strong natural tendency for biennial bearing remain predisposed to an alternating habit, even after a successful chemical thinning program has reduced the fruit number to a commercially acceptable level (personal observation by authors). In such situations, additional strategies are needed to restore consistent cropping.

Application of growth regulators $\mathrm{GA}_{3}$, $\mathrm{GA}_{4+7}$, or $\mathrm{GA}_{7}$ to apple trees in the nonfruiting year of the biennial bearing cycle can inhibit flower bud formation (Fulford, 1973; Marino and Greene, 1981; McArtney, 1994; McArtney and Li, 1998; Meador and Taylor, 1987; Schmidt et al., 2010), whereas application of ethephon (Williams, 1972) or NAA (Harley et al., 1958; McArtney et al., 2007) in the heavy cropping year of a biennial bearing cycle can stimulate flower bud formation. Williams (1972) reported that postharvest application of ethephon to young vigorous 'Wellspur Delicious' apple trees stimulated flower bud formation. Thus, the transition from vegetative to floral development may be triggered by a chemical stimuli relatively late in the season.

'York Imperial' is an important processing apple in Virginia and Pennsylvania that can develop a biennial bearing habit. Handthinning 'York Imperial' trees $8 \mathrm{~d}$ after bloom resulted in abundant fruit bud formation, whereas thinning later than $25 \mathrm{~d}$ after bloom did not effectively increase return bloom on trees with a heavy fruit set (Aldrich and Fletcher, 1932), suggesting that a signal inhibiting flower bud formation emanated from the fruit of this cultivar very early in the growing season. The combination of limb-ringing and fruit removal to establish 100 leaves per fruit stimulated fruit bud formation on 'York Imperial' apple trees when it was imposed before $60 \mathrm{~d}$ after full bloom but was less effective after this time (Magness et al., 1934). It was proposed that buds on high-vigor trees remain in a meristematic state later into the season compared with buds on low-vigor trees and presumably therefore respond to florigenic stimuli later than buds on less vigorous trees (Magness et al., 1934).

NAA directly stimulates flower development in apple (Harley et al., 1958). Applications of NAA in the heavy cropping year of a biennial bearing cycle increased the proportion of flowering spurs in the next year (McArtney et al., 2007). Applications of NAA to 'Golden Delicious' at weekly intervals during the month leading up to harvest (120 to $150 \mathrm{~d}$ after bloom) increased return bloom just as effectively as four biweekly summer applications during the period 60 to $100 \mathrm{~d}$ after bloom (McArtney et al., 2007). The florigenic activity of foliar NAA sprays applied during the month before harvest (McArtney et al., 2007) and of a postharvest ethephon application (Williams, 1972) is unexpected given these growth regulators were applied after the period when apple buds are believed to transition from vegetative to reproductive development.

Broadening of the meristem apex within the buds developing on 1-year-old wood of 
apple occurs during the period 21 to $42 \mathrm{~d}$ after bloom (Buban and Faust, 1982; Foster et al., 2003; Pratt et al., 1959) and this change provides the earliest physical indication of the transition to floral development. Doming of the apex follows soon after broadening, providing the first easily observable indication of the floral transition. Doming is typically observed 70 to $100 \mathrm{~d}$ after full bloom (Foster et al., 2003; Hirst and Ferree, 1995; Hoover et al., 2004; McArtney et al., 2001) and is relatively synchronized within buds sampled from wood of the same age (Foster et al., 2003; Hoover et al., 2004; McArtney et al., 2001). Doming of the meristem apex has not been observed later than $\approx 110 \mathrm{~d}$ after bloom, i.e., well before harvest of most apple cultivars. Thus, the timing of summer NAA sprays for return bloom coincides with the period during which buds are normally doming. In contrast, the application of NAA sprays during the month before harvest occurs well after buds have normally made this transition. The florigenic activity of preharvest NAA sprays for return bloom provides evidence to suggest that NAA can trigger floral development within vegetative buds relatively late in the season. Because ethephon sprays during the postharvest period are also florigenic (Williams, 1972), it may be possible that the positive effect of NAA on return bloom is mediated by an auxin-induced ethylene response (Curry, 1991).

The objectives of the present studies were to 1) evaluate the efficacy of summer NAA sprays for promotion of return bloom of 'York Imperial' and 'Golden Delicious' apple; 2) verify that weekly NAA applications during the month leading up to harvest are florigenic; 3) establish if ethylene is involved in the florigenic activity of NAA sprays; and 4) determine the time of floral transition in different growing environments and confirm that preharvest NAA sprays are applied after the developing buds have normally made the transition from vegetative to floral development.

\section{Materials and Methods}

Efficacy of summer NAA and ethephon sprays for promoting return bloom of 'York Imperial'. An experiment was initiated at the Alson H. Smith, Jr. Agricultural Research and Extension Center, Virginia Polytechnic Institute and State University, in Winchester, VA, in 2007 to evaluate the effect of chemical thinning and different NAA and ethephon treatments on return bloom of 'York Imperial' apples. The six treatments in this study were 1) an unthinned control; 2) a chemically thinned control with $1200 \mathrm{mg} \cdot \mathrm{L}^{-1}$ carbaryl (Sevin XLR; Bayer CropScience, Research Triangle Park, $\mathrm{NC})$ plus $75 \mathrm{mg} \cdot \mathrm{L}^{-1}$ 6-benzyladenine (6-BA, MaxCel; Valent USA, Walnut Creek, CA); 3) four applications (31 May, 11 June, 21 June, and 2 July) of $5 \mathrm{mg} \cdot \mathrm{L}^{-1} \mathrm{NAA}$ (Fruitone N; Amvac Chemical Corp., Los Angeles, CA) plus 225 $\mathrm{mg} \cdot \mathrm{L}^{-1}$ ethephon (Ethrel; Bayer CropScience); 4) three applications (31 May, 11 June, and 21 June) of $6.75 \mathrm{mg} \cdot \mathrm{L}^{-1} \mathrm{NAA}$ plus $300 \mathrm{mg} \cdot \mathrm{L}^{-1}$ ethephon; 5) two applications (31 May and
11 June) of $10 \mathrm{mg} \cdot \mathrm{L}^{-1} \mathrm{NAA}$ plus $450 \mathrm{mg} \cdot \mathrm{L}^{-1}$ ethephon; and 6) a single application (31 May) of $10 \mathrm{mg} \cdot \mathrm{L}^{-1}$ NAA plus $900 \mathrm{mg} \cdot \mathrm{L}^{-1}$ ethephon. The treatments were arranged in a randomized complete block design experiment with six blocks. The treatments were applied to singletree plots with a handgun to the point of drip. Full bloom in 2007 occurred on 25 Apr. All of the treatments except the unthinned control were chemically thinned on 10 May as in (2). Treatment effects on crop density in 2007 were evaluated from three sample limbs per tree by calculating the number of fruit on each limb after the completion of fruit drop. Crop density was expressed as the number of fruit per square centimeter limb cross-sectional area. Treatment effects on return bloom were measured as the percent of flowering spurs on each sample limb in 2008.

Effects of aminoethoxyvinylglycine on the efficacy of summer NAA and preharvest NAA programs for promoting return bloom. Experiments were conducted on 'Golden Delicious'/M.7 apples in 2006 (commercial orchard in Henderson County, NC) and 'York Imperial'/M.9 apples in 2008 (Alson H. Smith, Jr. Agricultural Research and Extension Center, Virginia Polytechnic Institute and State University, in Winchester, VA) to investigate the involvement of ethylene in NAA-induced stimulation of flower bud formation. The 'Golden Delicious' study included seven treatments: 1) control; 2) a summer NAA program of four biweekly applications of $5 \mathrm{mg} \cdot \mathrm{L}^{-1} \mathrm{NAA}$ (7 June, 19 June, 7 July, 20 July) (Fruitone N; Amvac Chemical Corp.); 3) summer NAA sprays as in (2) except the first application included $125 \mathrm{mg} \cdot \mathrm{L}^{-1}$ AVG; 4) a preharvest NAA program of four weekly sprays of $5 \mathrm{mg} \cdot \mathrm{L}^{-1}$ NAA beginning 4 weeks before harvest (9 Aug., 16 Aug., 24 Aug., 29 Aug.); 5) preharvest NAA sprays as in (4) except the first application included $125 \mathrm{mg} \cdot \mathrm{L}^{-1}$ AVG; 6) a summer ethephon program of two applications of $562 \mathrm{mg} \cdot \mathrm{L}^{-1}$ ethephon (Ethrel; Bayer CropScience) ( 7 June and 7 July); and 7) a summer ethephon program as in (6) except AVG was included with the first application at a concentration of $125 \mathrm{mg} \cdot \mathrm{L}^{-1}$. Full bloom of the 'Golden Delicious' trees in 2006 occurred on $18 \mathrm{Apr}$. The treatments were arranged in a randomized complete block design experiment with six blocks. The spray treatments in the 'Golden Delicious' study were applied to fully guarded single-tree plots with an airblast sprayer calibrated to deliver 1496 $\mathrm{L} \cdot \mathrm{ha}^{-1}$ (160 gal/acre). All of the trees received a standard thinning spray of $20 \mathrm{mg} \cdot \mathrm{L}^{-1} \mathrm{NAA}$ when the fruit were $10 \mathrm{~mm}$ in diameter. Return bloom in 2007 was assessed by counting the number of vegetative and floral spurs on two representative limbs per tree, each limb carrying a minimum of 100 spurs. From these data the percent of floral spurs on each limb was calculated.

The 'York Imperial'/M.9 study included seven treatments arranged in a randomized complete block design experiment with seven blocks. The treatments were 1) an unthinned control; (2) a chemically thinned control,
$500 \mathrm{mg} \cdot \mathrm{L}^{-1}$ carbaryl (Sevin XLR) plus $50 \mathrm{mg} \cdot \mathrm{L}^{-1}$ 6-BA (MaxCel; Valent USA) applied when the mean fruit diameter was $10 \mathrm{~mm}$; 3) four applications (5 June, 17 June, 26 June, 7 July) of $5 \mathrm{mg} \cdot \mathrm{L}^{-1}$ NAA (Fruitone L; Amvac Chemical Corp.) plus $225 \mathrm{mg} \cdot \mathrm{L}^{-1}$ ethephon (Ethrel; Bayer CropScience); 4) three applications (5 June, 17 June, 26 June) of $6.75 \mathrm{mg} \cdot \mathrm{L}^{-1} \mathrm{NAA}$ plus $300 \mathrm{mg} \cdot \mathrm{L}^{-1}$ ethephon; 5) two applications (5 June, 17 June) of $10 \mathrm{mg} \cdot \mathrm{L}^{-1} \mathrm{NAA}$ plus $450 \mathrm{mg} \cdot \mathrm{L}^{-1}$ ethephon; 6) a single application (5 June) of $10 \mathrm{mg} \cdot \mathrm{L}^{-1} \mathrm{NAA}$ plus $900 \mathrm{mg} \cdot \mathrm{L}^{-1}$ ethephon; and 7) four applications of NAA plus ethephon as in treatment (3) except that $250 \mathrm{mg} \cdot \mathrm{L}^{-1} \mathrm{AVG}$ was included in the first and third sprays. All of the treatments except the unthinned control were chemically thinned on 6 May as in treatment (2). The treatments were applied to fully guarded single-tree plots with seven replications arranged in a randomized complete block design experiment. The treatments were applied to single tree plots with a handgun to the point of drip. Full bloom of the 'York Imperial' trees in 2008 occurred on 25 Apr. Treatment effects on cropload (fruit $/ \mathrm{cm}^{2}$ limb cross-sectional area) were determined in two sample limbs per tree in 2008, and return bloom was assessed on the same two limbs in 2009 as the number of flower clusters per $\mathrm{cm}^{2}$ limb cross-sectional area and as the percent of floral spurs.

In a block of mature 'Golden Delicious'/ M.7 apple trees in Massachusetts 18 trees were selected that exhibited a uniformly heavy bloom in 2008. The trees were separated into six groups (replications) of three trees each. Within each group, trees were randomly assigned to receive one of following three treatments: Control, Summer NAA sprays, or Preharvest NAA sprays. Trees were in full bloom on May 14. Summer NAA sprays consisted of four biweekly applications (8 July, 27 July, 5 Aug., 19 Aug.) of $5 \mathrm{mg} \cdot \mathrm{L}^{-1}$ NAA. Preharvest NAA sprays consisted of four weekly sprays of $5 \mathrm{mg} \cdot \mathrm{L}^{-1}$ NAA beginning four weeks before harvest (9 Aug., 16 Aug., 24 Aug., 29 Aug.). The treatments were applied as a dilute spray with a hand gun. Return bloom was measured in 2009 on two sample limbs in each tree by calculating the flower cluster density (clusters/ $\mathrm{cm}^{2} \mathrm{limb}$ cross sectional area) and the proportion of floral buds separately for spurs and one-year old wood.

Time of transition to flowering in relation to NAA programs for promoting return bloom of 'Golden Delicious' at three different locations. Buds were sampled from mature 'Golden Delicious'/M.7 apple trees growing in North Carolina, Massachusetts, and Washington State during the 2008 growing season. One hundred non-fruiting buds were removed from 1-year-old wood on five (North Carolina, Massachusetts) or ten (Washington) trees at $\approx 14$-d intervals beginning $50 \mathrm{~d}$ after full bloom until harvest at each location. The buds were stored in fixative (HistoChoice; Amresco Inc., Solon, $\mathrm{OH}$ ) until dissection under a stereo microscopic dissection (Leica Stereo Zoom 6 Photo; Cambridge Instruments, Buffalo, NY) at $\times 40$ magnification. The stage of bud 
development was rated using the scale developed by Hoover et al. (2004): Stage 1, apical meristem flat (vegetative); Stage 2, apical meristem domed (floral commitment); Stage 3, bractlets developing on the terminal floral meristem; Stage 4, sepals clearly differentiated on the terminal floral mersistem and bractlets differentiated on the lateral floral meristems; and Stage 5, sepals clearly differentiated on the lateral floral meristems. The proportion of buds rated at Stage 2 (doming) was calculated at each sampling date to determine the time of floral commitment at each location.

Statistical analyses were performed using Statistical Analysis Software (SAS Inst., Cary, NC). Return bloom data (percent floral spurs) was arcsine-transformed to correct deficiencies in normality and homogeneity of variance before being submitted to an analysis of variance using the generalized linear model procedure in SAS. Means separations were performed using Duncan's multiple range test $(P \leq 0.05)$.

\section{Results and Discussion}

Return bloom of 'York Imperial' trees that were neither chemically thinned nor received summer NAA and ethephon sprays was low with fewer than $5 \%$ of spurs floral in the next year (Tables 1 and 2). These responses illustrate the severity of biennial bearing in this cultivar. Although chemical thinning significantly reduced crop density and increased return bloom of 'York Imperial' compared with unthinned control, the level of return bloom was still not more than $10 \%$ (Tables 1 and 2), which in our opinion is insufficient to ensure a commercially acceptable cropload. However, return bloom was higher when the chemical thinning spray was followed by summer NAA + ethephon sprays compared with chemical thinning alone. The summer NAA plus ethephon treatments resulted in more than $25 \%$ of spurs floral in the year after treatment, providing additional evidence for a direct stimulatory effect of NAA and/or ethephon on flower bud formation that is independent of, and additive to, a cropload effect. We estimate that a minimum of $25 \%$ of the spurs must be floral to produce a full commercial crop. These data demonstrate that a successful chemical thinning program was not enough to guarantee sufficient return bloom of this strongly biennial cultivar. In contrast, a successful chemical thinning program combined with summer NAA + ethephon sprays resulted in sufficient return bloom.

The efficacy of summer NAA plus ethephon sprays applied to 'York Imperial' in 2008 was unaffected by the ethylene biosynthesis inhibitor AVG (Table 2); however, AVG did reduce the efficacy of summer NAA sprays applied to 'Golden Delicious' in 2007 (Table 3). AVG was without effect on the efficacy of the NAA plus ethephon combination sprays applied to 'York Imperial', which was not unexpected because AVG would not have inhibited ethylene released from

Table 1. Effects of early summer naphthaleneacetic acid (NAA) and ethephon sprays applied in 2007 on return bloom of 'York Imperial'/M.9 apples in 2008 in Virginia. ${ }^{2}$

\begin{tabular}{|c|c|c|c|c|}
\hline \multirow{2}{*}{$\begin{array}{l}\text { Treatment } \\
\text { Control (not thinned) }\end{array}$} & \multirow[t]{2}{*}{$\begin{array}{l}\text { Application } \\
\text { (DAFB) }\end{array}$} & \multirow{2}{*}{$\begin{array}{c}\text { Crop density in } \\
2008 \text { (fruit } / \mathrm{cm}^{2} \\
\text { BCSA) } \\
10.3 \mathrm{a}^{\mathrm{y}}\end{array}$} & \multicolumn{2}{|c|}{$\begin{array}{l}\text { Return bloom } \\
\text { in } 2009 \\
\text { (\% floral spurs) }\end{array}$} \\
\hline & & & $0.3 \mathrm{a}$ & $(2.7)$ \\
\hline Chemically thinned & & $2.7 \mathrm{~b}$ & $14.9 \mathrm{~b}$ & (6.6) \\
\hline $\mathrm{NAA}^{\mathrm{y}}\left(5.0 \mathrm{mg} \cdot \mathrm{L}^{-1}\right)+$ ethephon $\left(225 \mathrm{mg} \cdot \mathrm{L}^{-1}\right)$ & $36,47,57,68$ & $3.2 \mathrm{~b}$ & $29.5 \mathrm{c}$ & $(24.2)$ \\
\hline NAA $\left(6.75 \mathrm{mg} \cdot \mathrm{L}^{-1}\right)+$ ethephon $\left(300 \mathrm{mg} \cdot \mathrm{L}^{-1}\right)$ & $36,47,57$ & $2.8 \mathrm{~b}$ & $27.2 \mathrm{c}$ & (20.9) \\
\hline NAA $\left(10.0 \mathrm{mg} \cdot \mathrm{L}^{-1}\right)+$ ethephon $\left(450 \mathrm{mg} \cdot \mathrm{L}^{-1}\right)$ & 36,47 & $1.7 \mathrm{~b}$ & $33.7 \mathrm{c}$ & $(30.8)$ \\
\hline NAA $\left(10.0 \mathrm{mg} \cdot \mathrm{L}^{-1}\right)+$ ethephon $\left(900 \mathrm{mg} \cdot \mathrm{L}^{-1}\right)$ & 36 & $2.3 \mathrm{~b}$ & $34.9 \mathrm{c}$ & (32.7) \\
\hline
\end{tabular}

${ }^{2}$ Return bloom data were arcsine square root transformed before analysis. Data in parentheses are the backtransformed means. Full bloom occurred on 25 Apr. All trees except for the control were chemically thinned with $1200 \mathrm{mg} \cdot \mathrm{L}^{-1}$ carbaryl $+75 \mathrm{mg} \cdot \mathrm{L}^{-1} 6$-BA on $10 \mathrm{May}$, when the fruit were $10 \mathrm{~mm}$ in diameter. ${ }^{y}$ Means with different letters within each column are significantly different at $P \leq 0.05$ as determined by Duncan's multiple range test.

$\mathrm{BCSA}=$ branch cross-sectional area; 6-BA = 6-benzyladenine; $\mathrm{DAFB}=$ days after full bloom.

Table 2. Effects of AVG on the efficacy of early summer NAA and ethephon sprays applied in 2008 on return bloom of 'York Imperial'/M.9 apples in 2009 in Virginia. ${ }^{2}$

\begin{tabular}{|c|c|c|c|c|}
\hline \multirow{2}{*}{$\frac{\text { Treatment }}{\text { Control (not thinned) }}$} & \multirow[t]{2}{*}{$\begin{array}{l}\text { Application } \\
\text { (DAFB) }\end{array}$} & \multirow{2}{*}{$\begin{array}{c}\text { Crop density in } \\
2008 \text { (fruit } / \mathrm{cm}^{2} \\
\text { BCSA) } \\
11.9 \mathrm{a}^{\mathrm{y}}\end{array}$} & \multicolumn{2}{|c|}{$\begin{array}{l}\text { Return bloom } \\
\text { in } 2009(\% \\
\text { floral spurs) }\end{array}$} \\
\hline & & & $1.2 \mathrm{a}$ & $(0.0)$ \\
\hline Chemically thinned & & $3.4 \mathrm{~b}$ & $19.2 \mathrm{~b}$ & $(10.8)$ \\
\hline NAA & 73 & & $22.5 \mathrm{bc}$ & (14. \\
\hline NA & 41 & & $34.0 \mathrm{c}$ & $(31$. \\
\hline NA & 41,53 & 3. & $33.9 \mathrm{c}$ & $(31.1)$ \\
\hline NAA $\left(10.0 \mathrm{mg} \cdot \mathrm{L}^{-1}\right)+$ ethephon $\left(900 \mathrm{mg} \cdot \mathrm{L}^{-1}\right)$ & 41 & $3.2 \mathrm{~b}$ & $34.9 \mathrm{c}$ & $(33.0)$ \\
\hline NAA $\left(5.0 \mathrm{mg} \cdot \mathrm{L}^{-1}\right)+$ ethephon $\left(225 \mathrm{mg} \cdot \mathrm{L}^{-1}\right)$ & $41,53,62,73$ & $3.5 \mathrm{~b}$ & $18.7 \mathrm{~b}$ & $(10.3)$ \\
\hline
\end{tabular}

${ }^{2}$ Return bloom data were arcsine square root transformed before analysis. Data in parentheses are the backtransformed means. Full bloom occurred on 25 Apr. All trees except for the control were chemically thinned with $500 \mathrm{mg} \cdot \mathrm{L}^{-1}$ carbaryl $+50 \mathrm{mg} \cdot \mathrm{L}^{-1} 6-\mathrm{BA}$ on 6 May.

${ }^{y}$ Means with different letters within each column are significantly different at $P \leq 0.05$ as determined by Duncan's multiple range test.

${ }^{x}$ AVG was included with the first and third sprays only (41 DAFB and 62 DAFB).

$\mathrm{AVG}=$ aminoethoxyvinylglycine; $\mathrm{NAA}=$ naphthaleneacetic acid; $\mathrm{DAFB}=$ days after full bloom; $\mathrm{BCSA}=$ branch cross-sectional area; 6-BA = 6-benzyladenine.

Table 3. Effects of NAA, ethephon, and AVG treatments in 2006 on return bloom of 'Golden Delicious'/ M.7 apples in $2007 .^{2}$

\begin{tabular}{|c|c|c|c|}
\hline \multirow{2}{*}{$\frac{\text { Treatment }}{\text { Control }}$} & \multirow[t]{2}{*}{$\begin{array}{l}\text { Application } \\
\text { (DAFB) }\end{array}$} & \multicolumn{2}{|c|}{$\begin{array}{l}\text { Return bloom in } 2007 \\
\text { (\% floral spurs) }\end{array}$} \\
\hline & & $19.2 \mathrm{a}^{\mathrm{y}}$ & $(10.9)$ \\
\hline Summer NAA $\left(5 \mathrm{mg} \cdot \mathrm{L}^{-1}\right)$ & $50,62,80,93$ & $54.3 \mathrm{c}$ & $(66.0)$ \\
\hline $\mathrm{AVG}^{\mathrm{x}}\left(125 \mathrm{mg} \cdot \mathrm{L}^{-1}\right)+$ summer NAA $\left(5 \mathrm{mg} \cdot \mathrm{L}^{-1}\right)$ & $50,62,80,93$ & $41.0 \mathrm{~b}$ & $(43.0)$ \\
\hline Preharvest NAA $\left(5 \mathrm{mg} \cdot \mathrm{L}^{-1}\right)$ & $113,120,128,133$ & $56.1 \mathrm{c}$ & $(68.8)$ \\
\hline $\operatorname{AVG}^{y}\left(125 \mathrm{mg} \cdot \mathrm{L}^{-1}\right)+$ preharvest NAA $\left(5 \mathrm{mg} \cdot \mathrm{L}^{-1}\right)$ & $113,120,128,133$ & $54.8 \mathrm{c}$ & $(66.8)$ \\
\hline Summer ethephon $\left(560 \mathrm{mg} \cdot \mathrm{L}^{-1}\right)$ & 50,80 & $41.1 \mathrm{~b}$ & $(43.3)$ \\
\hline $\mathrm{AVG}^{\mathrm{y}}\left(125 \mathrm{mg} \cdot \mathrm{L}^{-1}\right)+$ summer ethephon $\left(560 \mathrm{mg} \cdot \mathrm{L}^{-1}\right)$ & 50,80 & $38.5 \mathrm{~b}$ & $(38.8)$ \\
\hline
\end{tabular}

${ }^{2}$ Data were arcsine square root transformed before analysis. Data in parentheses are the back-transformed means. Full bloom occurred on $18 \mathrm{Apr}$. All trees were chemically thinned with $20 \mathrm{mg} \cdot \mathrm{L}^{-1} \mathrm{NAA}$ on 28 May. ${ }^{y}$ Means with different letters within each column are significantly different at $P \leq 0.05$ as determined by Duncan's multiple range test.

${ }^{\mathrm{x}} \mathrm{AVG}$ was only included with the first NAA or ethephon spray.

$\mathrm{NAA}=$ naphthaleneacetic acid $\mathrm{AVG}=$ aminoethoxyvinylglycine; $\mathrm{DAFB}=$ days after full bloom.

ethephon, which occurs through a physicochemical rather than a biochemical reaction. However, a partial reduction in efficacy of the summer NAA program for return bloom that occurred when AVG was applied with the first spray to 'Golden Delicious' implies that NAA-induced ethylene is involved in the return bloom response to NAA.

Preharvest NAA sprays applied to 'Golden Delicious' in 2007 increased return bloom in 2008 just as effectively as a summer NAA program (Table 3 ). Although only $11 \%$ of the spurs on control trees were floral, the summer NAA and preharvest NAA programs applied in 2006 increased the proportion of floral spurs in 2007 to $66 \%$ and $69 \%$, respectively. The efficacy of preharvest NAA sprays for promoting return bloom in the current study is consistent with previously reports (McArtney et al., 2007). Application of summer ethephon sprays to 'Golden Delicious' also effectively increased return bloom with $43 \%$ of the spurs floral in the year after treatment. Although summer ethephon sprays were less effective than NAA treatments in this study, they still provided 
a level of return bloom that was sufficient to produce a commercial crop. Combining AVG with the first spray in a preharvest NAA program or a summer ethephon program did not reduce their efficacy.

The timing of transition to floral development in 'Golden Delicious' buds, as determined by doming of the axillary meristem in non-fruiting buds, was relatively consistent among the three different growing regions (Fig. 1). Doming was first observed in buds that were sampled $64 \mathrm{~d}$ after bloom in North Carolina and Washington State; however, fewer than $5 \%$ of buds collected at these two locations exhibited doming at that time. Doming peaked at 78 to $92 \mathrm{~d}$ after bloom and relatively few buds exhibited doming later than $106 \mathrm{~d}$ after bloom. Thus, the transition from vegetative to floral development in 'Golden Delicious' buds was completed by $106 \mathrm{~d}$ after bloom in all three locations. Hoover et al. (2004) reported that different apple cultivars exhibited unique patterns of floral development with doming occurring earlier in 'Fuji' ( $86 \mathrm{~d}$ after bloom) compared with 'Braeburn', 'Gala', or 'Pacific Rose' (104 to $112 \mathrm{~d}$ after bloom). Data from the present study suggest that the timing of floral development in 'Golden Delicious' buds is similar to 'Fuji' and earlier than 'Gala', 'Braeburn', or 'Pacific Rose'.

Application of summer NAA sprays to 'Golden Delicious' in 2008 increased the percentage of floral buds on spur buds and buds on 1-year-old wood in Massachusetts (Table 4). Preharvest NAA sprays were

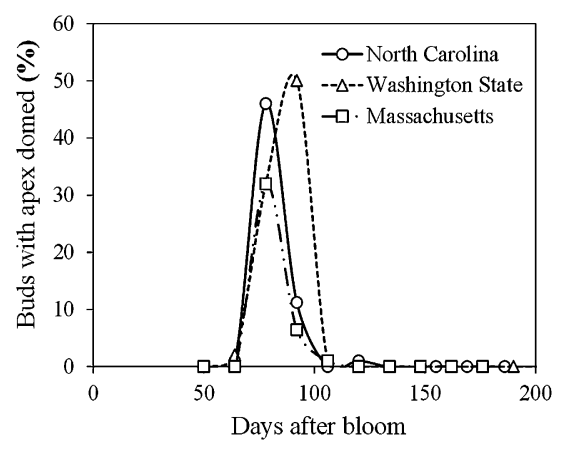

Fig. 1. Changes in the proportion of 'Golden Delicious' buds exhibiting floral morphogenesis, i.e., with a domed meristem apex, over time in three U.S. states. Each data point is derived from a sample of 100 buds removed at $\approx 14-\mathrm{d}$ intervals starting $50 \mathrm{~d}$ after bloom in 2008 .

Table 4. Effects of summer NAA and preharvest NAA sprays applied in 2008 on return bloom of 'Golden Delicious'/M.7 apple trees in Massachusetts in 2009. ${ }^{\mathrm{z}}$

\begin{tabular}{|c|c|c|c|c|c|c|}
\hline \multirow[b]{3}{*}{ Treatment } & \multirow[b]{3}{*}{ Application (DAFB) } & \multicolumn{5}{|c|}{ Return bloom in 2009} \\
\hline & & \multicolumn{3}{|c|}{$\begin{array}{l}\text { Flower cluster density } \\
\text { (clusters } / \mathrm{cm}^{2} \text { LCSA) }\end{array}$} & \multicolumn{2}{|c|}{$\begin{array}{l}\text { Percent floral } \\
\text { buds }\end{array}$} \\
\hline & & $\overline{\text { Spurs }}$ & One year old & Total & Spurs & One year old \\
\hline Control & & $6.8 \mathrm{a}^{2}$ & $3.8 \mathrm{a}$ & $10.6 \mathrm{a}$ & $78 \mathrm{a}$ & $36 \mathrm{a}$ \\
\hline Summer NAA & $56,70,84,98$ & $8.5 \mathrm{a}$ & $6.2 \mathrm{~b}$ & $14.7 \mathrm{ab}$ & $90 \mathrm{~b}$ & $57 \mathrm{~b}$ \\
\hline Preharvest NAA & $121,128,135,142$ & $9.5 \mathrm{a}$ & $6.9 \mathrm{~b}$ & $16.4 \mathrm{~b}$ & $86 \mathrm{ab}$ & $50 \mathrm{ab}$ \\
\hline
\end{tabular}

${ }^{2}$ Summer NAA sprays $\left(5 \mathrm{mg} \cdot \mathrm{L}^{-1}\right)$ were applied $56 \mathrm{~d}, 70 \mathrm{~d}, 84 \mathrm{~d}$, and $98 \mathrm{~d}$ after bloom. Preharvest NAA sprays $\left(5 \mathrm{mg} \cdot \mathrm{L}^{-1}\right)$ were applied at weekly intervals during the month before harvest $(121 \mathrm{~d}, 128 \mathrm{~d}, 135 \mathrm{~d}$, and $142 \mathrm{~d}$ after bloom).

${ }^{y}$ Means with different letters within each column are significantly different at $P \leq 0.05$ as determined by Duncan's multiple range test.

$\mathrm{NAA}=$ naphthaleneacetic acid; DAFB $=$ days after full bloom; LCSA $=$ limb cross-sectional area. ethylene (McArtney et al., 2007; Williams, 1972), and an analog of 9,10-ketol-octadecadienoic acid (Kittikorn et al., 2013) exhibits florigenic activity in apple. In this work, we have shown that applying NAA during the period when meristems are normally doming promotes flower bud formation. We also report that NAA applications during the month before harvest promote flowering, indicating that NAA triggers floral development in quiescent vegetative buds. Chailakhyan (1936) first proposed the concept of a mobile floral stimulus in plants. Recent research has revealed that the proteins encoded by FLOWERING LOCUS T (FT) in Arabidopsis and its orthologs in other plant species is a key component of florigen (Corbesier et al., 2007; Lin et al., 2007; Tamaki et al., 2007; Zeevart, 2006). Kittikorn et al. (2013) reported that application of 9,10-ketol-octadecadienoic acid increased MdFT1 expression and flower bud formation in apple. Because NAA sprays at different times during the growing season are florigenic, analysis of gene expression after NAA treatments may provide an alternative approach to studying the endogenous control of flower bud formation in apple.

\section{Literature Cited}

Aldrich, W.W. 1932. Effect of fruit thinning upon carbohydrate accumulation, formation of fruit buds, and set of bloom in apple trees. Proc. Amer. Soc. Hort. Sci. 28:599-604.

Aldrich, W.W. and L.A. Fletcher. 1932. Relation of foliage system and fruit thinning to biennial bearing in apples. Proc. Amer. Soc. Hort. Sci. 29:56-61.

Buban, T. and M. Faust. 1982. Flower bud induction in apple trees: Internal control and differentiation. Hort. Rev. 4:174-203.

Chailakhyan, M.Kh. 1936. New facts in support of the hormonal theory of plant development. C. R. Acad. Sci. URSS 13:79-83.

Corbesier, L., C. Vincent, S. Jang, F. Fornara, Q. Fan, I. Searle, A. Giakountis, S. Farrona, L. Gissot, C. Turnbull, and G. Coupland. 2007. FT protein movement contributes to long-distance signaling in floral induction of Arabidopsis. Science 316:1030-1033.

Curry, E.A. 1991. NAA-induced ethylene and ACC in 'Delicious' spur tissues: Changes with temperature and time. J. Amer. Soc. Hort. Sci. 116:846-850.

Foster, T., R. Johnston, and A. Seleznyova. 2003. A morphological and quantitative characterization of early floral development in apple (Malus $\times$ domestica Borkh.). Ann. Bot. (Lond.) 92:199-206.

Fulford, R. 1973. Flower initiation effects of gibberellin sprays. Rep. East Malling Res. Stn. 1972:93

Harley, C.P. and M.P. Masure. 1937. Thinning apples with reference to alternate bearing. Wash. State Hort. Assoc. Proc. 33:27-30.

Harley, C.P., M.P. Masure, and J.R. Magness. 1934. Fruit thinning and biennial bearing in Yellow Newton apples. Proc. Amer. Soc. Hort. Sci. 30:330-331.

Harley, C.P., H.H. Moon, and L.O. Regeimbal. 1958. Evidence that postbloom apple thinning sprays of naphthaleneacetic acid increase blossom bud formation. Proc. Amer. Soc. Hort. Sci. 72:52-56.

Hirst, P. and D. Ferree. 1995. Rootstock effects on the flowering of 'Delicious' apple. I. Bud development. J. Amer. Soc. Hort. Sci. 120:1010-1017. 
Hoover, E., N. De Silva, S. McArtney, and P. Hirst. 2004. Bud development and floral morphogenesis in four apple cultivars. J. Hort. Sci. Biotechnol. 79:981-984.

Kittikorn, M., K. Okawa, H. Ohara, and S. Kondo. 2013. Application of an analog of 9,10-ketoloctadecadienoic acid (KODA), affected flower bud formation and MdTFL1 and MdFT1 gene expressions in apple buds under heavy-crop and shade conditions. J. Amer. Soc. Hort. Sci. 138:102-107.

Lin, M.K., H. Belanger, Y.J. Lee, E. Varkonyi-Gasic, K. Taoka, E. Miura, B. Xoconostle-Cázares, K. Gendler, R.A. Jorgensen, B. Phinney, T.J. Lough, and W.J. Lucas. 2007. FLOWERING LOCUS T protein may act as the long-distance florigenic signal in the cucurbits. Plant Cell 19:1488-1506.

Looney, N.E., R.P. Pharis, and M. Noma. 1985. Promotion of flowering in apple trees with gibberellin A4 and C-3 epi-gibberellin A4. Planta 165:292-294.

Magness, J.R., L.A. Fletcher, and W.W. Aldrich. 1934. Time during which fruit-bud formation in apples may be influenced in the ShenandoahCumberland fruit districts. Proc. Amer. Soc. Hort. Sci. 30:313-318.

Marino, F. and D.W. Greene. 1981. Involvement of gibberellins in the biennial bearing of 'Early McIntosh' apples. J. Amer. Soc. Hort. Sci. 106:593-596.

McArtney, S.J. 1994. Exogenous gibberellin affects biennial bearing and the fruit shape of 'Braeburn' apple. N. Z. J. Crop Hort. Sci. 22:343-436.

McArtney, S.J., E.M. Hoover, P.M. Hirst, and I.R. Brooking. 2001. Seasonal variation in the onset and duration of flower development in 'Royal Gala' apple buds. J. Hort. Sci. Biotechnol. 76:536-540.

McArtney, S.J. and S.H. Li. 1998. Selective inhibition of flowering on 'Braeburn' apple trees with gibberellins. HortScience 33:699 700 .

McArtney, S., D. Unrath, J. Obermiller, and A. Green. 2007. Naphthaleneacetic acid, ethephon, and gibberellin A4 + A7 have variable effects on flesh firmness and return bloom of apple. HortTechnology 17:32-38.

Meador, D.B. and B.H. Taylor. 1987. Effect of early season foliar sprays of GA4/7 on russeting and return bloom of 'Golden Delicious' apple. HortScience 22:412-415.

Pratt, C., J. Einset, and M. Zahur. 1959. Radiation damage in apple shoot apices. Amer. J. Bot. 46:537-544.

Schmidt, T., J. McFerson, D.C. Elfving, and M. Whiting. 2010. Practical gibberellic acid programs for mitigation of biennial bearing in apple. Acta Hort. 884:663-670.

Tamaki, S, S. Matsuo, H.L. Wong, S. Yokoi, and K. Shimamoto. 2007. Hd3a protein is a mobile flowering signal in rice. Science 316:10331036.

Williams, M.W. 1972. Induction of spur and flower bud formation in young apple trees with chemical growth retardants. J. Amer. Soc. Hort. Sci. 97:210-212.

Zeevart, J.A.D. 2006. Florigen coming of age after 70 years. Plant Cell 18:1783-1789. 